USSR, stating that it would be useful to get acquainted with the structure and principles of organizing the oldest open-air museums in Europe, to find out how important European museums are, and they have not resolved problems yet. However, the trip failed.

In 1962, an acquaintance handed M. Zam a copy of the Polish newspaper «Standar Molody» for November 27 with the note «Open Air Museum». It mentioned plans to open several open-air museums in Poland in the fields of architecture, archeology, ethnography near Warsaw and in Chersk. In October 1966, M. Sikorski managed to visit Poland and evaluate the achievements of his Polish colleagues in the creation of the Scans. In December 1970, with a view to sharing his experience, M. Sikorsky visited Czechoslovakia, in November 1976 - Sri Lanka and India. The Pereyaslav scholars followed closely the creation of the Lithuanian Museum of National Life in Rumshishkes (founded in 1966), which reflects the traditional rural life of the Lithuanians of the 19th and early 20th centuries of four historical regions of Lithuania. M. Zham planned to visit it in 1972, but failed.

In the end of the $60 \mathrm{~s}$ of the XX century, in Pereyaslavsk scansen the first organizational works were done, the full exposition was formed. At that time, his project had no precedents in Ukraine, so the path to the realization of this idea was difficult and long. Foreign experience in creating open-air ethnographic exhibitions was especially useful, as the museum practice of Ukraine still lacked theoretical knowledge, polished methodology, clear principles of museum studies, international standards, and good work experience. The approaches of Pereyaslav museums to this new, methodically and practically not developed business, were creative and original. The experience of its founders was useful for creating other museums of folk architecture and life in Ukraine.

\title{
References:
}

1. Sikorskij, M. I. (1966). The open-air Ethnographic Museum of Pereyaslav-Khmelnitsky. MUSEUM, vol. XIX, no 3, pp. 187-188.

\section{AT THE ORIGINS OF GERMAN CLASSICAL ARCHEOLOGY: ADOLF FURTWÄNGLER}

\section{Oleksii Prysiazhniuk $^{1}$}

DOI: https://doi.org/10.30525/978-9934-588-11-2_34

Possessing versatile and deep knowledge in his field, distinguished by amazing energy and productivity, conducting all his research on the basis of a broad historical horizons, Adolf Furtwängler (1853-1907) for 33 years of his scientific, in the full sense of the word, work, was able to enrich classical archeology with a number of

\footnotetext{
${ }^{1}$ South Ukrainian National Pedagogical University named after K.D. Ushynsky, Ukraine 
works, both large and small in volume, but always interesting and lively in content. Without dwelling on the mass of Furtwängler's articles scattered over various periodicals and collections, articles devoted to the publication of new monuments of classical antiquity, a new explanation of the monuments previously known, we only note those works of Furtwängler that are most important as in the breadth of the task assigned to them, and as the importance of the issues discussed in them [1, p. 79].

In 1876, Furtwängler, who was then 23 years old, published a small work entitled: «Der Dornauszieher und der Knabe mit der Gans». In it, taking the famous statues «The Boy Removing the Splinter» and «The Boy with the Goose» as the starting point of his research, Furtwängler is trying not only to sketch out the history of genre sculpture from the Greeks, but also to come to a definition of what a genre is in art in general. Already in this youthful work by Furtwängler, his characteristic features were manifested: the desire for a broad historical statement of the question, courage in resolving the task left and the absence of any admiration for authorities.

The participation of Furtwängler in the campaign of the Olympic excavations and his special studies with the bronzes found during the excavations, caused the appearance, in 1879, of Furtwängler's new work again, of a more or less, general nature, although based on detailed preliminary work: «Die Bronzefunde aus Olympia und deren kunstgeschichtliche Bedeutung». In this work, Furtwengler presented the history of the development of ancient Greek art in bronze from the VIII to VI centuries BC, and especially valuable in this work was an indication of the influence that oriental art had on Greek archaic, especially in its decorative motives. This work was a prelude to that monumental publication of the Olympic bronzes and other small findings in Olympia, which was published in 1890, as the fourth volume of the general publication «Olympia». And in this work of a descriptive, cataloging nature, Furtwängler again lays the foundation for the historical principle: to show the main trends of Greek culture on Olympic bronzes [1, p. 80].

Furtwängler's stay in Greece in the late 1870s resulted in two publications in collaboration with Leszke dedicated to Mycenaean ceramics: «Mykenische Tongefäße» (1879) and «Mykenische Vasen» (1886). In these publications, the material that was of great interest at that time to the scientific world, under the influence of Schliemann's excavations, was first published and brought into the system. And if the authors of these works, as it turned out later, due to Cretan finds, were mistaken, Mycenae and Argolis were considered the main center of Mycenaean culture in general, nevertheless, the classification of Mycenaean ceramics proposed by them remains, in its main foundations, still valid today.

From 1880 to 1894 Furtwängler was the curator of the Berlin Antiquarium, and during this time he worked hard to replenish his collections, as well as to catalog them. In the period from 1883 to 1887, two large volumes appeared, describing the Saburovsky collection, with an introduction containing research work on some issues related to the monumental monuments of the Greek afterlife. Classes in the collection of vases of the Antiquarium led Furtwängler to be published in two volumes of «Beschreibung der Vasensammlung im Antiquarium» (1885), and carvings of the same congregation brought to light «Beschreibung der geschnitten Steine im 
Antiquarium» (1896). Both the first and second catalogs are again built on a historical basis, with the most serious attention paid to a stylistic analysis of the described monuments and their groups [2, p. 877].

By the end of Furtwängler's stay in Berlin, there appeared the appearance of his composition, which on the part of some provoked fierce attacks on the author, on the part of others was enthusiastically greeted. Exactly «Meisterwerke der griechischen Plastik» (1893), also translated into English (Masterpieces of Greek sculpture, London, 1895). The main idea underlying this work can be briefly expressed as follows: since Brunn, who outlined the main features of the history of Greek art in his works and gave characteristics of Greek artists, since this could be borrowed from the news of ancient writers, scholars are usually content to repeat what Brunn did, and only from time to time they add to the finished fabric the decoration of one or another of the selected art monuments. Furtwängler's «Meisterwerke der griechischen Plastik» of Greek sculpture. Since the originals of Greek art, with very few, albeit brilliant, exceptions, have reached us only secondary or even third-rate, it is necessary to turn to the most careful study of the surviving copies, and among them try to find copies of famous originals, using, on the one hand, literature - information about artists and their works, and on the other hand, referring to the comparative stylistic analysis of preserved copies. It is hardly possible to doubt the justice of the main idea expressed by Furtwängler. But questions and perplexities of a purely methodical nature arise: first of all, it is necessary to prove that the Roman copyists only copied famous originals; then it is necessary to establish how the copyists treated the originals - slavishly or more, or less freely; finally, stylistic analysis is always, involuntarily, largely subjective. Furtwängler with great courage, but at the same time and with no less apologetic overcomes all these issues. He painted a brilliant picture of the development of Greek sculpture in the 5th -4 th centuries, but far from everything in this picture is equally convincing and thorough; bright colors are visible, but the exact drawing is not felt. But even with due skepticism to the general construction «Meisterwerke der griechischen Plastik», if you consider a lot of them unproven and exaggerated, still there are many positive results (of which the most brilliant is the search for a copy of Athena of Lemnos Phidias), a lot of observations that facilitate the way for further research [2, p. 878].

In 1894, Furtwängler moved to Munich. The first 6 years of his stay in Munich were dedicated to him, among other works, to the final processing, perhaps of the largest and most mature work, which he had been doing for 15 years. It is his «Die antiken Gemmen. Geschichte der Steinschneidekunst im klassischen Altertum» (1900) in three volumes, of which the first contains 67 tables that reproduce 3,600 plots of gems, the second contains a description and explanation of the tables, and the third gives a history of the development of the art of carving on precious stones from distant eras to the time of the late empire. Furtwängler, faithful to his historical research method, introduces gems into the general history of classical art in this work and simultaneously explores a number of questions of a more general nature, such as the nature of Mycenaean culture and the subsequent archaic era, the role of Ionia in this era, and Etruscan art. In this regard, the third volume is, by its nature, a supplement to «Meisterwerke», where many 
issues of classical art are raised, mainly in the fifth and fourth centuries, but where there is almost no research on earlier eras.

From 1901 until the end of his life, Furtwängler's main interest was focused on excavations in Aegina, among which death also caught him. Furtwängler was not able to complete the description and research of all the results of the excavations. In a large volume that appeared in 1906 under the title «Aegina. Heiligtum der Aphaia» Only the results of excavations of that famous temple, the sculptures of the pediments of which were opened in 1812 and are now stored in the Munich Glyptothek, are compared and investigated. During the excavations, Furtwängler managed to find new fragments of pediment sculptures, many other monuments and, finally, thanks to one of the inscriptions found, to establish the name of the mysterious deity of Afaya, to whom the temple was dedicated. All the data obtained during excavations, with the involvement of, of course, and previously known material, Furtwengler used to recreate the history of the shrine of Afaya, from its most ancient times until the first decades of the fifth century. Furtwängler paid special attention to the pediment sculptures of the temple. The Furtwängler offers a new reconstruction of them, along the way gives an outline of the development of Greek pediment compositions, discusses in detail the question of the art of Aegina sculptors. And here again there are a lot of detailed comparisons on a common, widely taken, historical basis [2, p. 879].

Furtwängler's other great work, undertaken by him in collaboration with the artist Reichhold, remained unfinished, «Griechische Vasenmalerei. Auswahl hervorragender Vasenbilder» (1900) with explanatory text. This monumental publication laid, one might say, the basis for the study of the history of vase painting among the Greeks. And if the publication «Griechische Vasenmalerei» was completed and equipped with the introduction promised by Furtwängler about the general development of vase painting, then we would undoubtedly have a full history of vase painting, written probably more or less subjectively and not without exaggeration and hobbies, like everything that came from the pen Furtwängler, but the story is lively and informative [2, p. 880].

Furtwängler was known to the general public mainly as the first whistleblower of one of the grandiose fakes of the beginning of the twentieth century: acquired by the Louvre and which became a kind of celebrity for Tiara Saitafern. And if N. I. Veselovsky was the first in the press to say that tiara was a falsification, then Furtwängler was the first to prove it (in the Cosmopolis magazine for 1896 and in the appendix to his studios, released the same year under the title Intermezzi Furtwängler, however, has the honor of proving the falsity of the bronze statuette of Apollo in the collection of Count Strogonov in St. Petersburg and a number of other fakes. Having spent his entire life in direct contact with ancient monuments, having traveled all the museums of the old and new worlds, having reviewed a lot of private collections, Furtwängler acquired a «sharp eye» in recognizing the genuine from the fake and when the French reproached him for recognizing the tiara fake after a 15-minute inspection, Furtwängler laughing, remarked that he had only $\mathrm{n}$ minutes to recognize the falsification. With his works, Furtwängler introduced into scientific use a huge number of monuments, until then either completely unknown or not attracting 
much attention. With his interpretation of them, he significantly contributed to the deepening and expansion of stylistic analysis, which has now become the main basis of any classical archaeological research both in Germany and abroad.

\section{References:}

1. Zhebelev, S. A. (1923). Vvedenie v arkheologiyu. Chast' I. Istoriya arkheologicheskogo znaniya [Introduction to archeology. Part I. History of archaeological knowledge]. Petrograd : Nauka i shkola, pp.79-80.

2. Zhebelev, S. A. (1907). Adol'f Furtvengler. Nekrolog [Adolf Furtwängler. Necrologue]. Zhurnal ministerstva narodnogo prosveshcheniya [Ministry of Education Magazine].

\section{HISTORIOGRAPHIC MATERIALS FROM THE RESEARCH OF PYSANKARSTVO IN POLTAVA REGION}

\section{Viktor Tkachenko ${ }^{1}$}

DOI: https://doi.org/10.30525/978-9934-588-11-2_35

Pysankarstvo, as a component of traditional culture, at the end of the XIX beginning of the XX centuries existed throughout the territory of Ukraine, and the study of archival documents on this topic allows us to more fully disclose its development in the 20s of XX century in Poltava region. After all, the 20-30s of the twentieth century are characterized by a negative attitude of the Soviet authorities to religion and folk rites, customs and beliefs in general.

An unusual belief was recorded by P. Kovbasiuk in Poltava region. It concerns the conduct of the peasant economy. Namely, what needs to be done at Easter so that cattle are kept. After all, family welfare depended mainly on the state of the economy [1, ark. 54]. In his notes we find rare words of the Easter greeting poem, which was voiced by the Chumaks (salt traders) when they went to the houses to chrystosuvatysia (exchange a triple kiss as an Easter greeting ) [2, ark. 13 st.-14].

The celebration of Radonitsa and the use of red Easter eggs are mentioned in the message of M. Belokon from the farmstead of Sypatino of Malo-Pereschepynsky district of Poltava region [7, ark. 265].

From the collected and sent materials to the Ethnographic Commission by Cowba Michael from the village of Aleksandrivka in Poltava region we also see the facts of the existence of pysankarstvo in the village. In the entries of 1929 to the national calendar, the author, telling about the celebration of Easter, drew and sent some samples of eggs that existed in the village. It is noted that the little boys went from home to home on Easter and congratulated versely on the holiday, as well as played with Easter eggs [8, ark. 178-178].

\footnotetext{
${ }^{1}$ Research Fellow of the National Historical and Ethnographic Reserve «Pereiaslav», Ukraine 